\title{
Late Pleistocene Hystrix (Acanthion) brachyura Linnaeus 1758 from the Fuchsluken Cave Near Saalfeld (Thuringia, Germany) - A Porcupine and Hyena Den and Contribution to their Palaeobiogeography in Europe
}

\author{
Cajus Godehard Diedrich*
}

\author{
PaleoLogic, Nansenstr. 8, D-33790 Halle/Westph., Germany and Speleological Institute Emil Racovita, Frumoasa 31, \\ RO-010986 Bukarest, Romania
}

\begin{abstract}
Rare Late Pleistocene porcupine remains of Hystrix (Atherurus) brachyura Linnaeus 1758 are described from the Fuchsluken Cave, a small gypsum karst cavity at the Rote Berg on the Giebelstein near Saalfeld (Thuringia, Central Germany). The cave was used during the Eemian and mainly Early Weichselian (around 120.000-75.000 BP) by spotted hyena clans of Crocuta crocuta spelaea (Goldfuss 1823), which imported prey that resulted in a large bone accumulation in and around the cave. It was also used in the short term by porcupines as their den, such as proven for several Eemian to Early Weichselian cave faunas in Central Europe, especially Germany and Czech Republic, recently. In the cave recycled-by-hyenas cracked megafauna bones were found, on which they had chewed all around. These typically nibbled bones with parallel bite scratches were also found at other European caves such as presented here for two more new Hystrix cave sites in the Moravian Karst (Czech Republic) and indirectly prove their presence at more and more cave sites in Central Europe. Here, the recently learned 21 Late Pleistocene porcupine sites with skeletal material and more often the indirect proof by chewed bones are presented in an overview. Nearly all are cave localities, often being small cavities or the entrance parts of small caves were used as porcupine dens, as is proved here in the Fuchsluken Cave near Saalfeld. In many cases the porcupines used hyena dens and recycled their accumulated bone rubbish.
\end{abstract}

\section{INTRODUCTION}

Late Pleistocene porcupine remains are extremely rare in Europe [1] and are recorded here only for the second time in northern Germany. The first Late Pleistocene finds were mentioned in south Germany from Siegmarsbrunn and the Zwergenloch and Hasenloch Caves near Pottenstein, Bavaria $[1,2]$ which were named "Hystrix spelaea" after their finds in caves (Fig. 1). Younger recorded remains of northern Germany are from Burgtonna [3]. The here-described bone material from the Rote Berg Cave at the Giebelstein near Saalfeld (Thuringia, Central Germany, Latitude: 50.6370; Longitude: 11.4238; Elevation: 410m) (Figs. 2, 3) was excavated between 1904 and 1907 by different people. This locality "Rother Berg" was mentioned and described briefly with finds $[4,5]$ long time ago.

The first descriptions of this bone material was referred to as Eemian to Weichselian age and was only listed incompletely with many different micro- and macromammal species, as well as frogs and birds [6,7]. Only Allactaga bones were figured with the interpretation of an Early Weichselian cold steppe environment [8]. The bone material was not under new studies, especially taphonomically, and was most recently identified with the restudy of all material as one of the very important hyena den sites in Thuringia. This small cave is the largest of two small hyena den caves in the Röblitzer Gypsum Karst area. Others include the Döbritzer Cave hyena den at Pößneck, whereas the well-

*Address correspondence to this author at the PaleoLogic, Nansenstr. 8, D33790 Halle/Westph., Germany and Speleological Institute Emil Racovita, Frumoasa 31, RO-010986 Bukarest, Romania; E-mail: cdiedri@gmx.net known and historically described Lindental Cave hyena den $[9,10]$ is more far in Gera and destroyed.

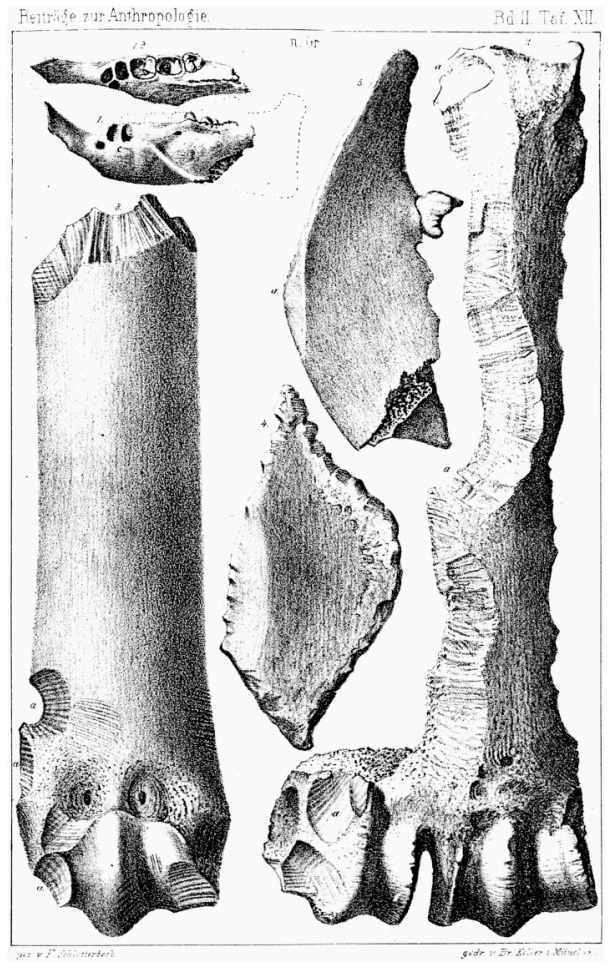

Fig. (1). Historical plate of the oldest reported Late Pleistocene porcupine remains of Germany (one mandible) and to those attributed cheweing marks on horse, bovid and cave bear bones, which were found in the hyena and Hystrix Zwergloch Cave den near Pottenstein, Bavaria, South-Germany (from Ranke 1879). 


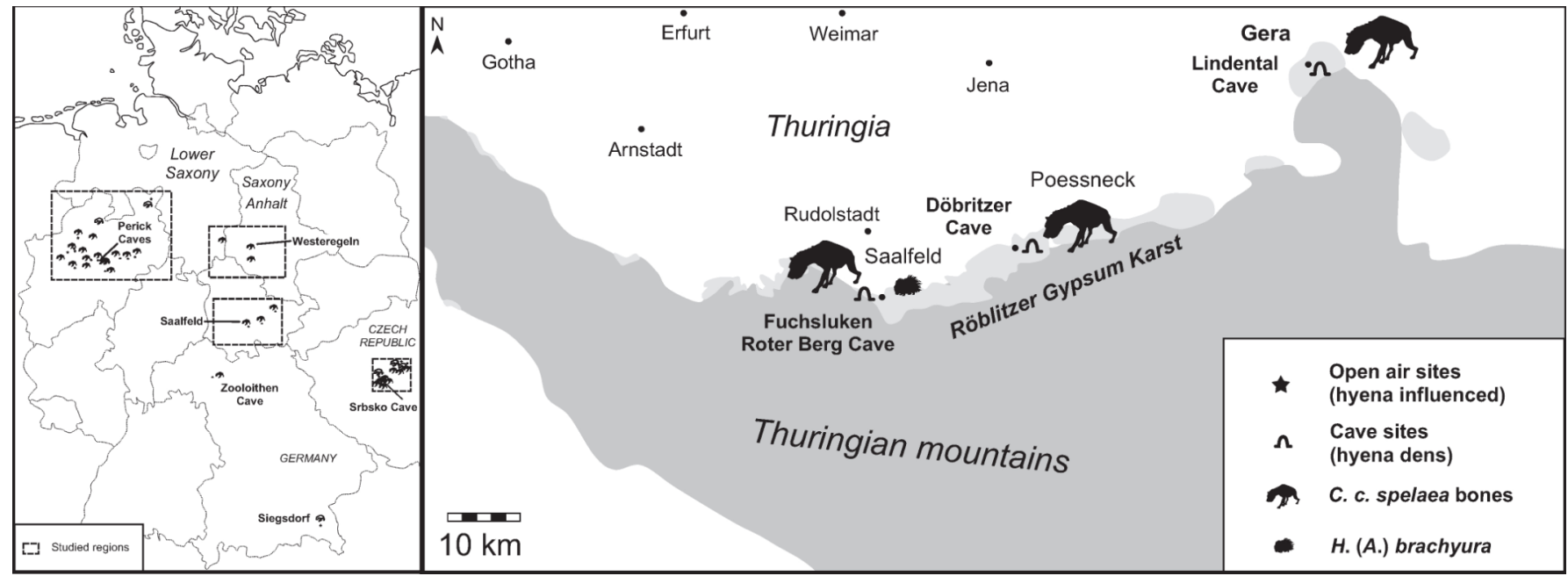

Fig. (2). Position of the Ice Age spotted hyena Crocuta crocuta spelaea (Goldfuss 1823) den Fuchsluken Cave on the Rote Berg near Saalfeld and other hyena den sites in the German province Thuringia. On the left in the frames other studied areas with hyena den sites in Germany and Czech Republic. Three hyena den sites Fuchsluken Cave, Döbritzer Cave and Lindenthal cave recently can be identified as such localities with prey bone accumulations.

\section{MATERIALS AND METHODOLOGY}

Four collections were studied, however only one of the Stadtmuseum im Franziskanerkloster Saalfeld (abbreviation $=$ SMS) still has preserved the here-described Hystrix material. This collection makes-up the Meyer collection, labelled in 1904, which was recently prepared and inventoried completely. This collection is the most important for the taphonomical analyses because it contains mostly incomplete and chewed bones or bone fragments; about 500 bones and teeth. The largest collection, which seems to be more selective with more complete bones, is in the Museum for Natural history at the Humboldt University Berlin (abbreviation = MB) and belongs to the coll. "K." labelled in 1907. Comparative bone material with Hystrix chewing marks were studied in the Anthropos-Museum Brno $($ abbreviation $=\mathbf{A M B})$.

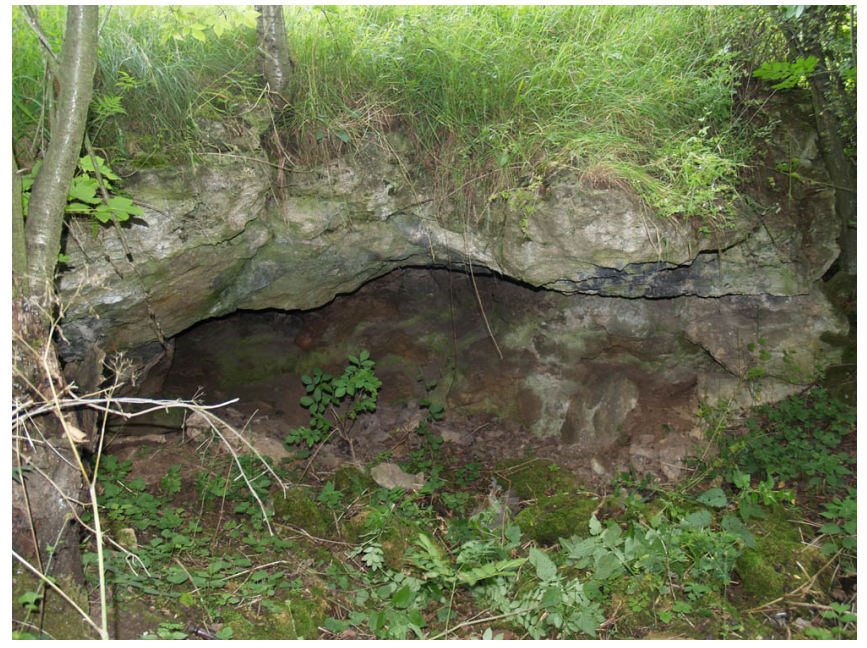

Fig. (3). The Hystrix (Acanthion) brachyura Linnaeus, 1758 small cave site Fuchsluken Cave porcupine and hyena den at the Giebelstein near Saalfeld (Thuringia, Central Germany).

This material was studied and newly determined. The hyena teeth were especially often misidentified as belonging to other carnivores, especially cave bears. Therefore the amount of hyena remains is now quite large (about 200 bones and teeth). A third small number of bones are stored in the Naturkundemuseum Gera (abbreviation $=$ NMG). All in all there are about 1.500 bones and teeth from large to small animals including mega mammals, birds and micro mammals. The macro mammal material is comprised of about 800 bones. For new, different studies, the historical Meyer collection was completely cleaned, prepared, conservated and inventoried new by the company PaleoLogic. Some marked tooth material was left unprepared for future geochemical or genetics analyses.

The listed fauna $[6,7]$ from the Rote Berg was partly newly determined here. The macrofauna reflects with the most material the hyena prey, which is a mixture of warm (Emian) and cold (Early Weichselian) animals. It consists of the Eemian warm period magamammals such as Stephanorhinus kirchbergensis (Jaeger 1839), Dama dama (Linnaeus 1758), Sus scrofa Linnaeus 1758, or Capreolus capreolus (Linnaeus 1758). The cold or steppe fauna of the Early Weichselian is: Coeleodonta antiquitatais (Blumenbach 1809), Bison priscus Bojanus 1827, Equus ferus przewalskii Poljakov, 1881, Equus hydruntinus Regalia, 1907, Rangifer tarandus (Linnaeus 1758) and Alopex lagopus (Linnaeus 1758). Also the here-described Hystrix (A.) brachyura Linnaeus 1758 seem to belong to the cold period steppe fauna. Indifferent faunal elements are present with: Megaloceros giganteus (Blumenbach 1799), Cervus elaphus Linnaeus 1758, Capra ibex Linnaeus 1758, and the carnivores Panthera leo spelaea (Goldfuss 1810), Crocuta crocuta spelaea (Goldfuss 1823) or Canis lupus subsp. Linnaeus 1758, Vulpes vulpes (Linnaeus 1758) or Meles meles (Linnaeus 1758). Finally, even Ursus spelaeus Rosenmüller 1794 is present in the fauna, which will be presented in more detail in further taphonomic and paleoecological descriptions in relation to the hyenas. Here only the rare porcupine remains and the Hystrix-related chewed bones are presented as a result of their rareness [1] and importance. 
Order Rodentia Bodwich 1821

Family Hystricidae Fischer 1817

Genus Hystrix Linnaeus 1758

Subgenus Hystrix (Acanthion) Cuvier 1823

\section{Hystrix (Acanthion) brachyura Linnaeus 1758}

Cranial Material: One left lower jaw fragment with three teeth $\left(\mathrm{P}_{4}, \mathrm{M}_{1-2}\right)$ and two isolated upper jaw cheek teeth $\left(? \mathrm{M}^{1}\right)$, and finally an incisive tooth (Figs. 4, 5). All teeth are semi-rubbed and from an adult animal, possibly only one individual, but a maximum of two porcupines. All the teeth are quite small and are $8 \mathrm{~mm}$ in width. The crown height of the $\mathrm{P}_{4}$ is $5 \mathrm{~mm}$ and of the $\mathrm{M}_{2}, 14 \mathrm{~mm}$. The upper jaw cheek tooth is $7 \mathrm{~mm}$ in width with a crown height of $10 \mathrm{~mm}$. One cheek tooth is missing parts of the enamel (Fig. 5). The enamel folds are redrawn for a better comparison to other published material. As described [11], those are very variable and depend on their stage of usage. As seen in the lower jaw the rubbing is even much different in the anterior to posterior teeth (Fig. 4.1).

Indirect prove of Hystrix: Two bones and one tooth fragment have typical Hystrix chew marks. These marks are flat, rectangular and more or less parallel scratches of 3-4 $\mathrm{mm}$ in width and irregular lengths. Sometimes in these depressions there are more slight parallel scratches resulting from a not normal sharp incisive. One bone fragment can no longer be determined. This fragment has bipolar chewing (Fig. 5.1) so both ends have sharp corners. A second larger bone fragment is quite interesting for two reasons. This fragment was produced by hyenas from a bovid humerus (Fig. 5.2). Here the bite marks are u-shaped depressions, often elongated resulting from the incisive teeth, whereas triangular impressions resulted from the lower jaw M1 and upper jaw P4 cracking scissors (Fig. 5.2b), which is described and figured [12] on intensively chewed woolly rhinoceros prey bones from an open air hyena den site in Central Germany. Both, porcupine and hyena bite marks are well distinguishable, whereas the unipolar nibbling stick was left by hyenas and was chewed after by porcupines. Also other smaller rodent marks are much less in the incisive width bite marks. Those mouse bite scratches are also figured for the hyena open air den site Bad Wildungen Biedensteg on Coelodonta bones [12]. As is typical in hyena dens, such bone fragments were nibbled again and again
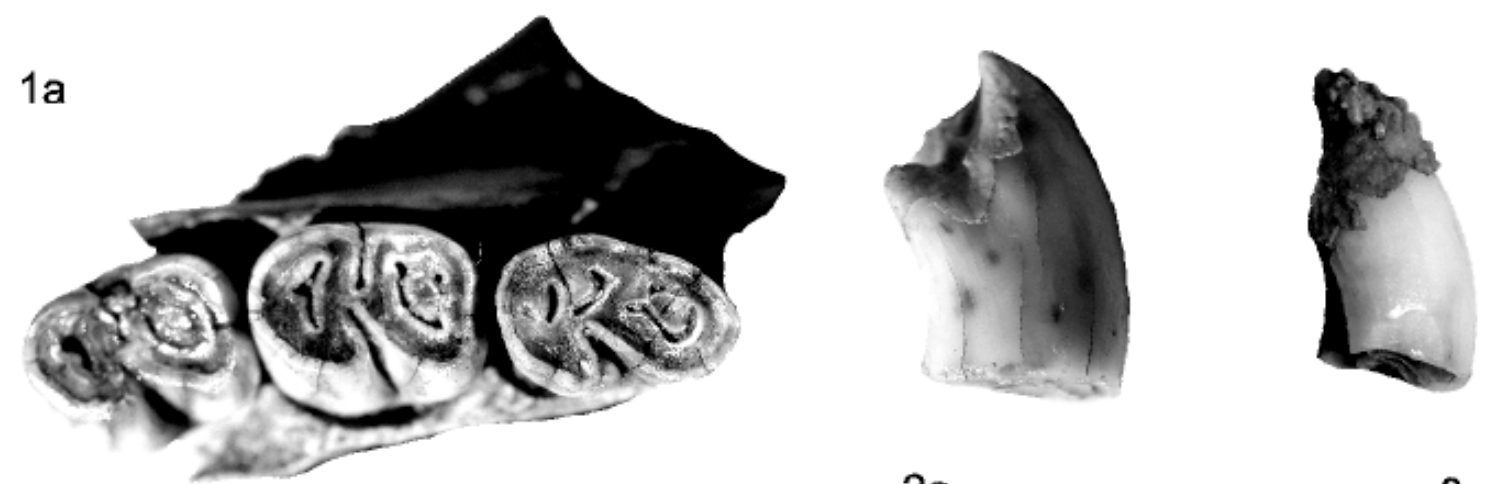

$2 a$

$3 a$
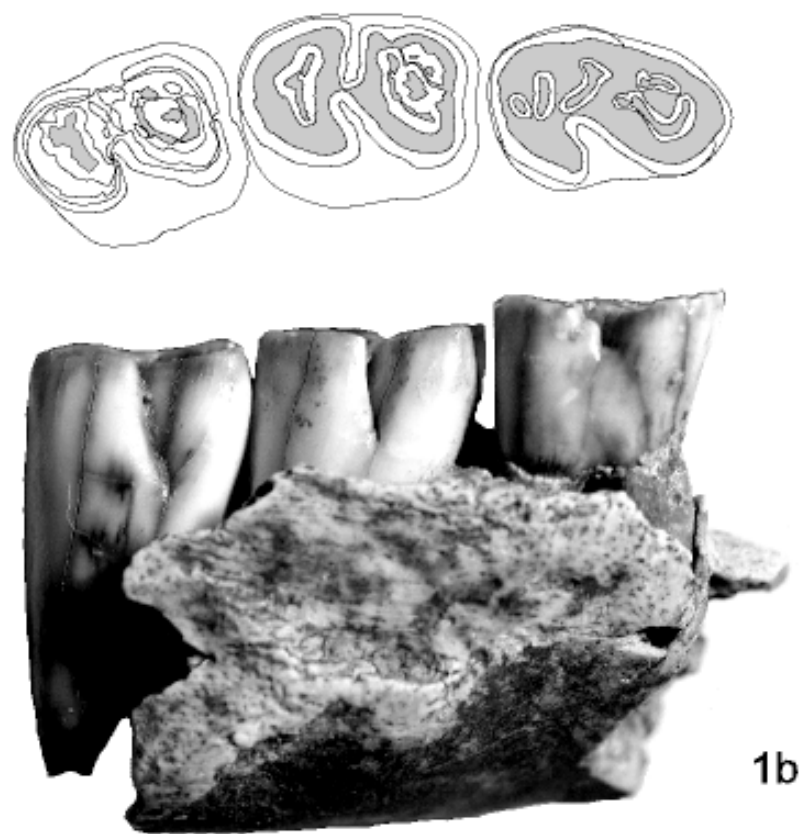

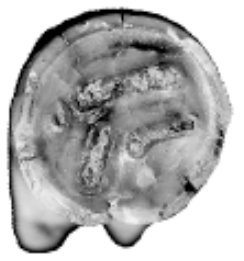

$2 b$

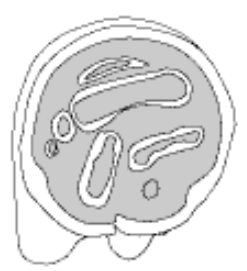

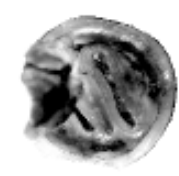

$3 b$

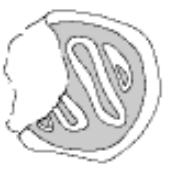

Fig. (4). Hystrix (Acanthion) brachyura Linnaeus 1758 remains from the Fuchsluken Cave porcupine and hyena den at the Giebelstein near Saalfeld (Thuringia, Central Germany). 1. Right lower jaw fragment (SMS RoteB-1), a. dorsal, b. lateral. 2. Isolated upper jaw cheek tooth (SMS RoteB-2), a. occlusal, b. labial. 3. Isolated upper jaw cheek tooth (SMS RoteB-3), a. occlusal, b. labial. 

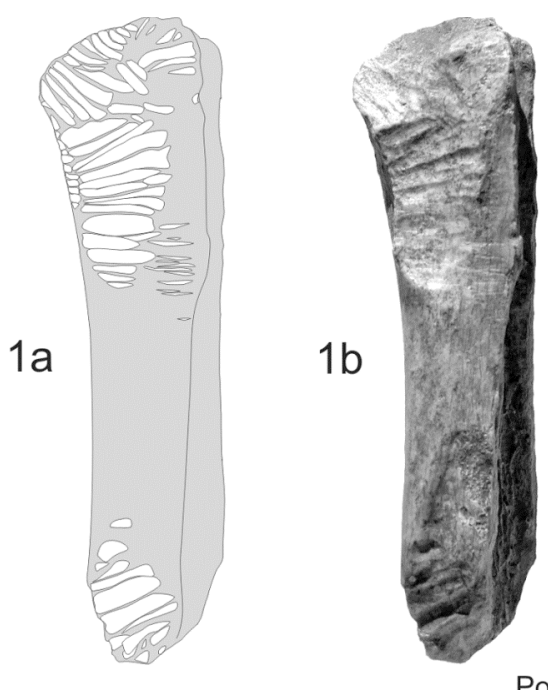

$1 c$

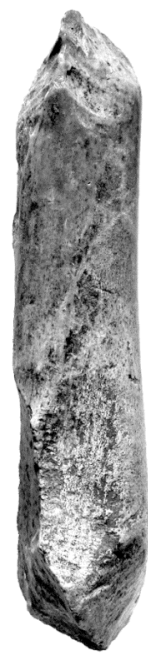

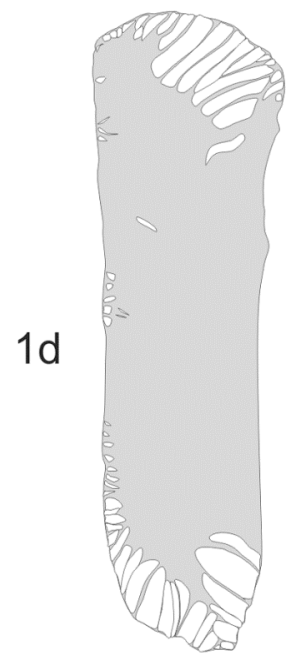
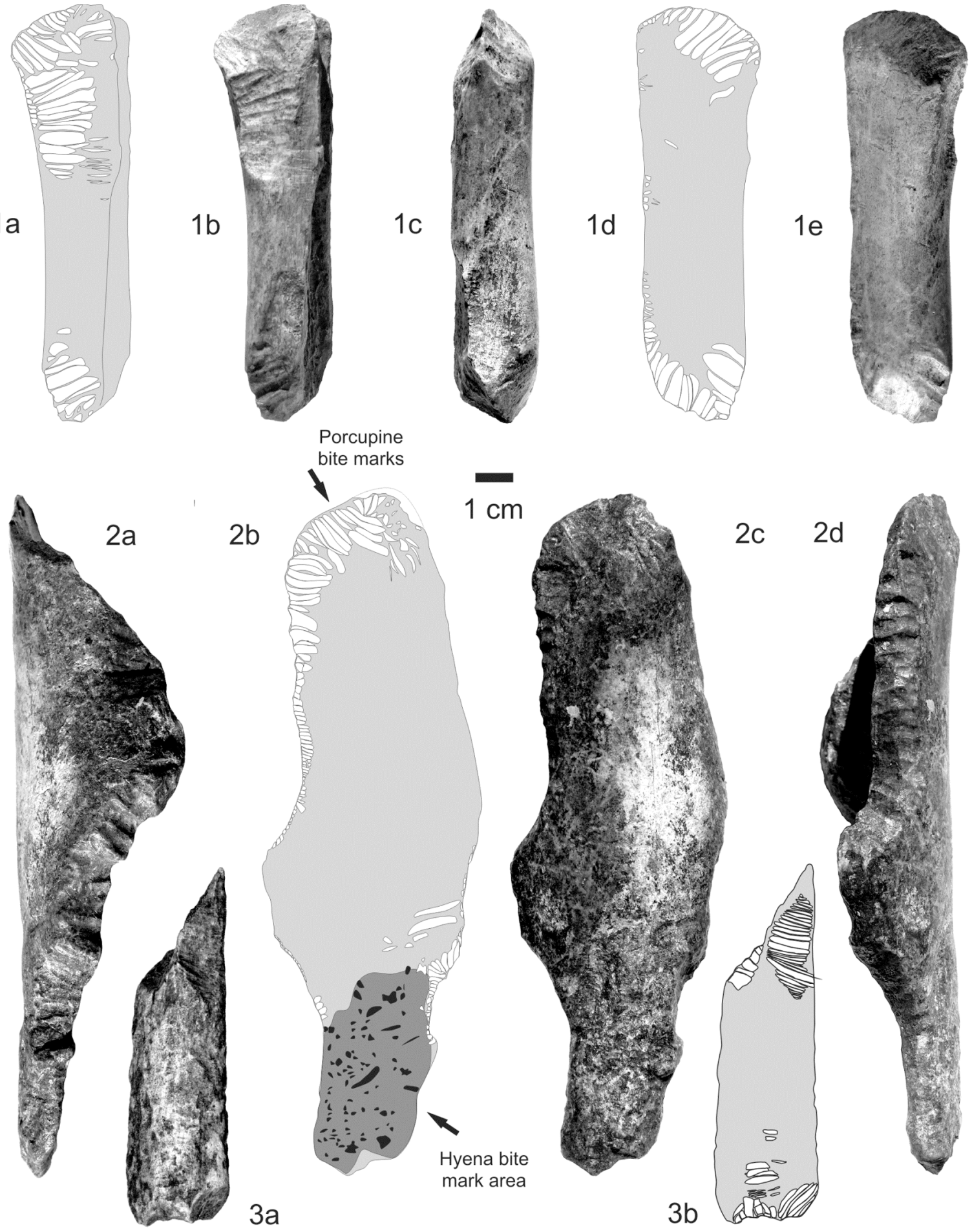

\section{Porcupine}

bite marks

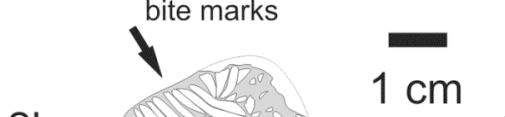

$3 a$
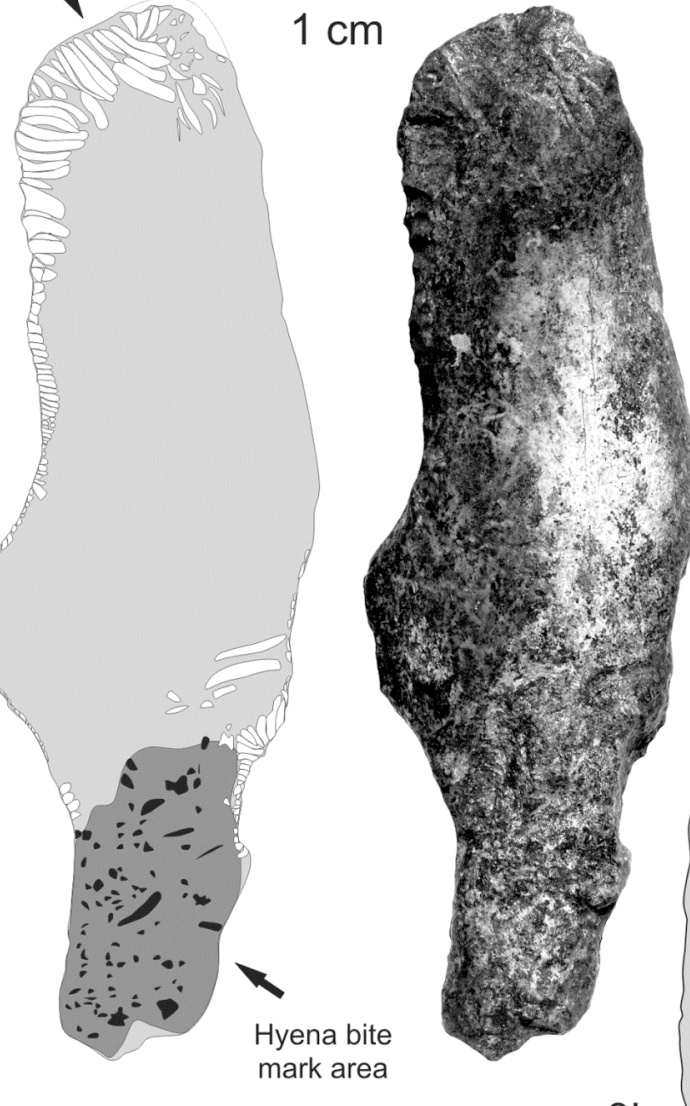

2c

$2 d$

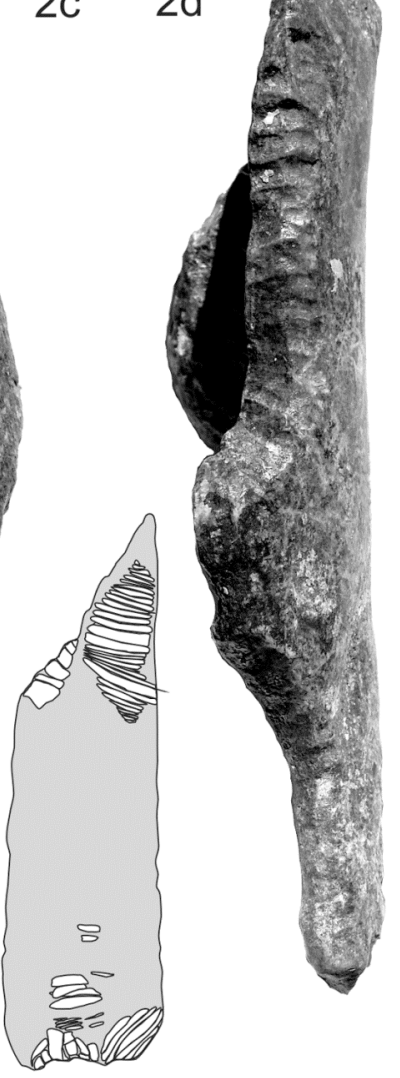

Fig. (5). Hystrix (Acanthion) brachyura Linnaeus 1758 chewed hyena prey bones from the Fuchsluken Cave porcupine and hyena den at the Giebelstein near Saalfeld (Thuringia, Central Germany). 1. Bone fragment (SMS RoteB-4). 2. Bovid humerus fragment which was first used as an "unipolar nibbling stick" by hyenas. It was later recycled by porcupines (SMS RoteB-5). 3. Deer antler fragment chewed bipolar (SMS RoteB-7). White = chew marks and zones, grey $=$ bone.

over hours resulting unipolar or by rotations bipolar nibbling sticks [13]. In the lower part of the here figured bone fragment the area is strongly chewed and many triangular to oval, often interconnected, impressions resulted from the carnivore's teeth. After hyenas left this mainly chewed bone piece, a porcupine later nibbled nearly all around the corners and over scratched even hyena bite marks (Fig. 5.2). Finally a deer antler fragment was chewed bipolar (Fig. 5.3).

\section{DISCUSSION}

Hundreds of high-crowned cheek teeth from Hystrix specimens from the Euro-Asiatic Pleistocene in the collections of European and Asiatic institutions have been 

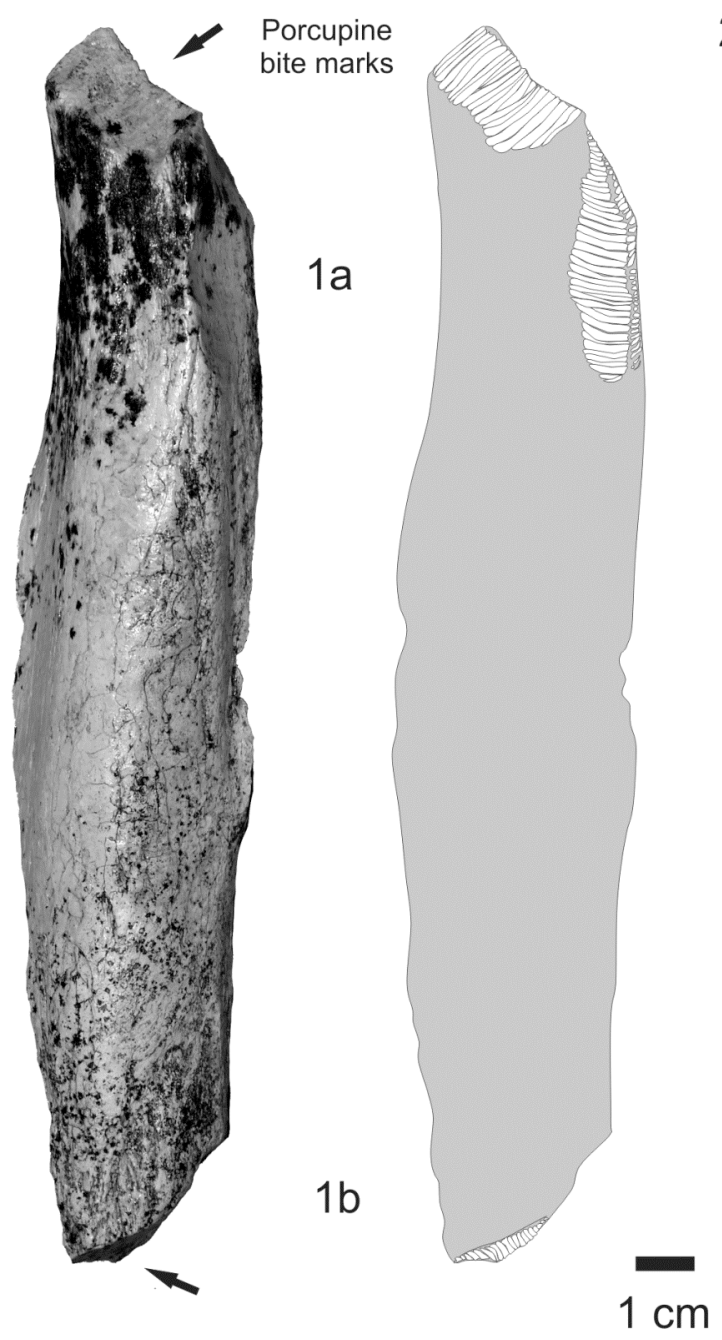

$2 a$
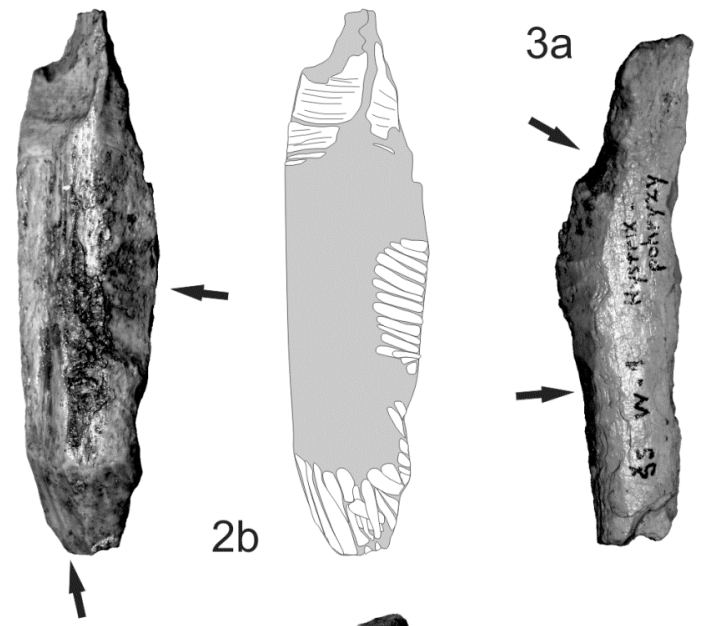

$4 b$

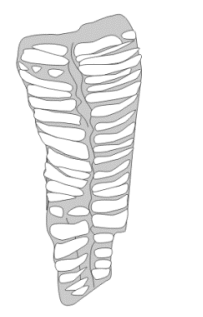

$5 a$

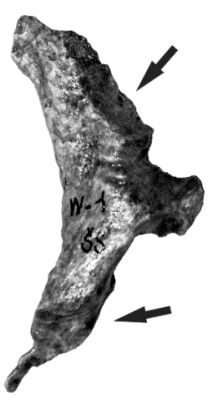

$4 a$

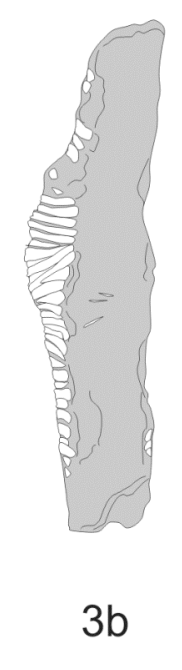

Fig. (6). Hystrix (Acanthion) brachyura Linnaeus 1758 chewed hyena prey bones from Moravian Caves (Czech Republic). 1. Bone fragment from the Javorka hyena and porcupine den cave (AMB OK80144). 2. Bone fragment from the Javorka hyena and porcupine den cave (AMB OK88144). 3. Bone fragment from the Javorka hyena and porcupine den cave (AMB OK89108). 4. Bone fragment from the Javorka hyena and porcupine den cave (AMB OK88145). 5. Bone fragment from the Javorka hyena and porcupine den cave (AMB OK87983).

compared with extant species for a revision of the genus [1]. Additionally a review was given about the extant genera and species of the family. The European Late Pleistocene $H$. (A.) vinogradovi Argyropulo 1941 is considered to be a synonym of $H$. (Acanthion) brachyura Linnaeus 1758 [1] in which the small-sized tooth material from the Fuchsluken Cave fits well.

Besides the few porcupine bones, which is dominated by teeth in Europe (possibly postcranial material is mostly overlooked) the indirect proof given by chewed bones becomes more important to understanding the distribution of these rodents, which used the Pleistocene caves and cavities. Hystrix chewed bones also are recently figured from three Polish cave sites without mentioning the tracemaker [14]. Similar traces, up to 3-4 $\mathrm{mm}$ in width rectangular scratches mostly all around bones, can be presented here on three bones from the German Fuchsluken Cave hyena and porcupine den (Fig. 5) and Czech hyena and porcupine den caves (Figs. 6, 7). One all over chewed bovid humerus fragment, cracked before by hyenas, found in the cave of the Fuchsluken must have resulted from porcupine feeding activity in the cave itself. Similar chewed bones with the same trace type were also figured from the Kartstein near Mechernich (Northern Eifel Mountains, West-Germany) [7]. Even similar chew marks described as "Machichnus" by [15] for large rodent scratch marks on turtle carapax and other bones

the Miocene of northern Czech Republic (Ahníkov) were recently revised to be of Miocene porcupine Hystrix $(H$.) parvae origin [16]. Similar chewed turtle carapax fragments were found recently in the first provable and oldest (Miocene age) porcupine den cave in the Bohemian Karst (PO2 Cave in Plešivec) of Central Europe [16], in which rich tooth material was also found. Some other chewed bone fragments are also present, some of them again with porcupine bite scratches.

The porcupine fossils can be compared palaeoecologically to the North-African extant crested porcupine Hystrix $(H$.) cristata which lived south of the Alps, but not north of them during the Late Pleistocene [8]. This currently living porcupine is generally a herbivore and eats bark, roots, tubers, rhizomes, bulbs, fallen fruit and 


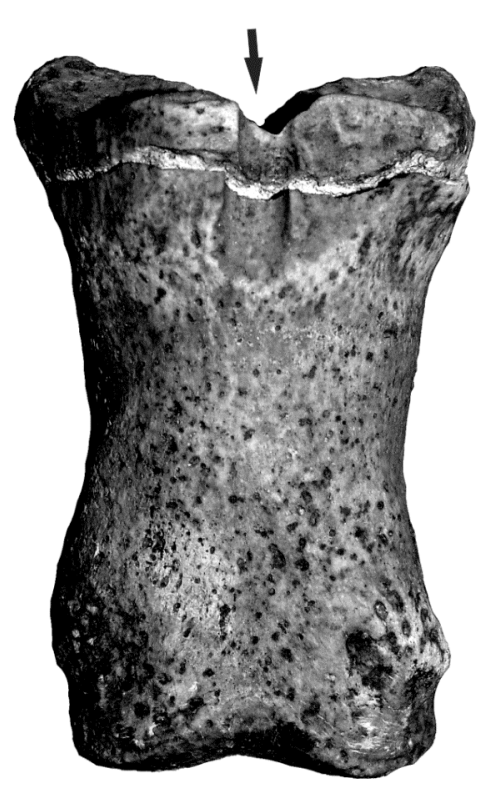

$1 a$

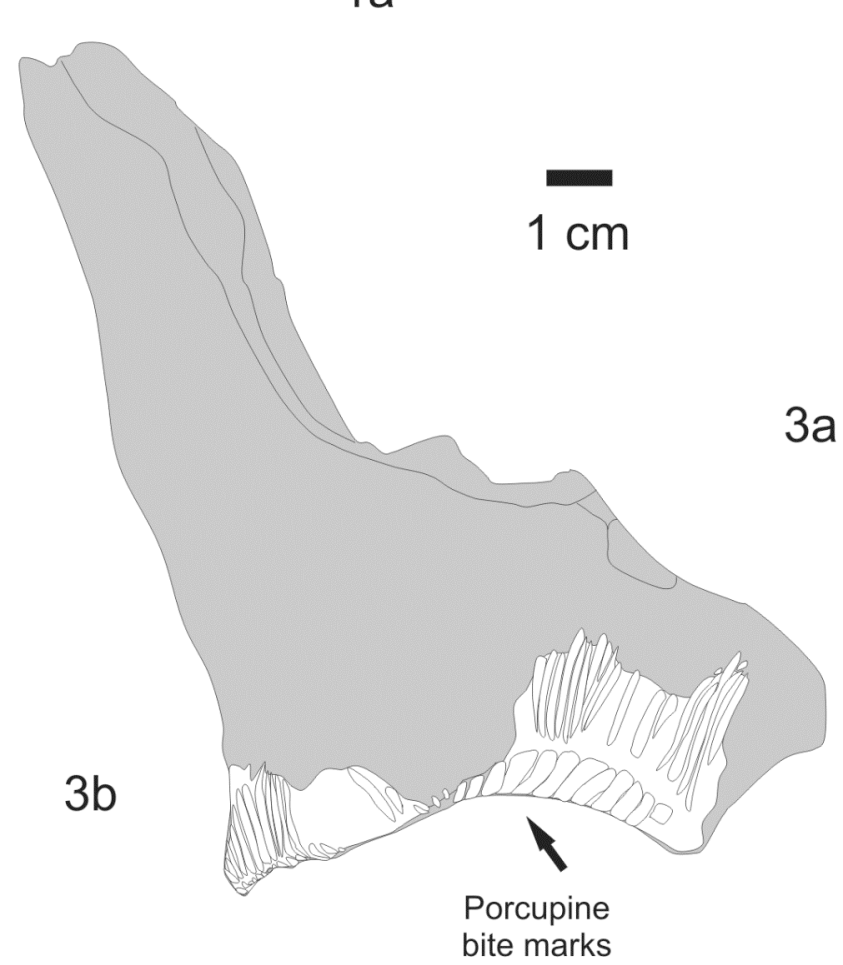

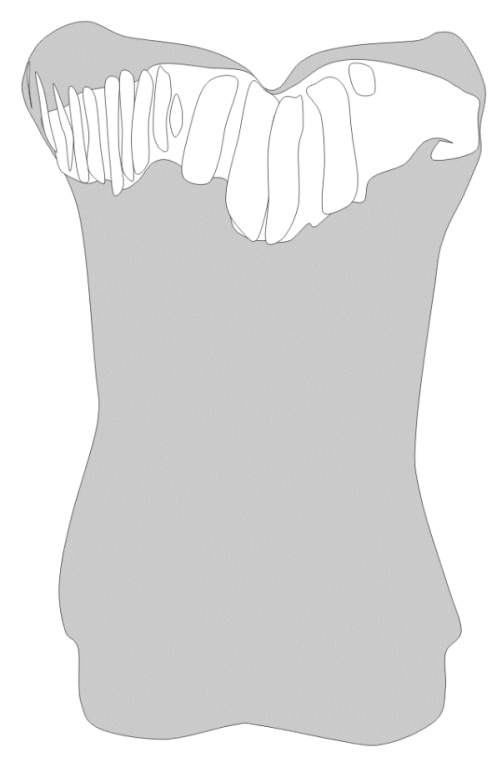

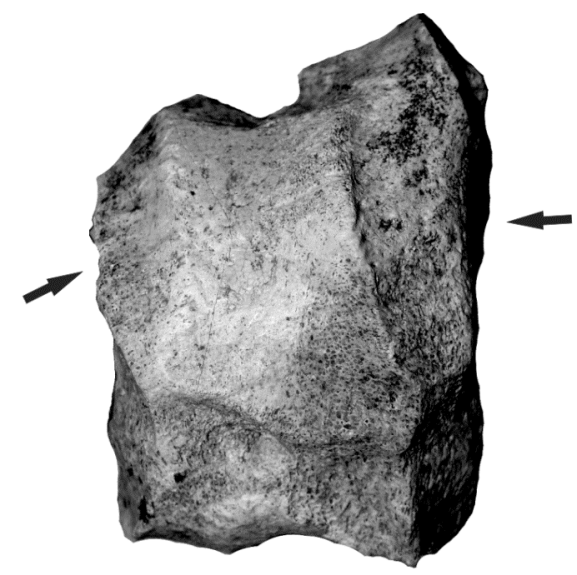

$2 a$

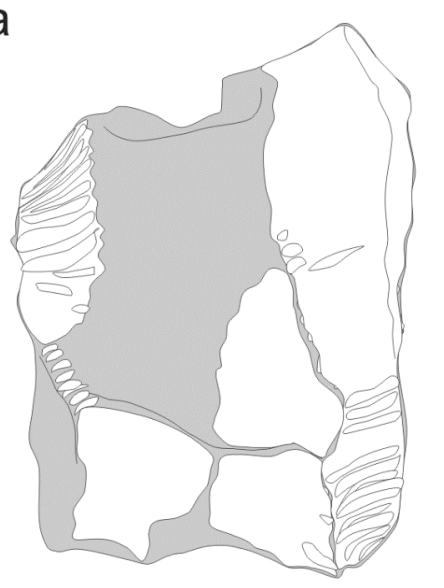

Fig. (7). Hystrix (Acanthion) brachyura Linnaeus 1758 chewed hyena prey bones from Bohemian Caves (Czech Republic). 1. Phalanx II of Equus sp. from the Svédův stůl hyena and porcupine den cave (AMB OK29727). 2. Astragal of a bovid/cervid from the Javorka hyena and porcupine den cave (AMB OK80145). 3. Scapula of a bovid from the Reporyje-Kalvarie hyena den and porcupine cave (AMB without No.).

cultivated crops, but occasionally consumes insects, and small vertebrates and even carrion are on its food list [17, 18]. In addition, this modern porcupine species commonly chews on bones for calcium and to sharpen its incisors [17, 18]. Therefore, bone consumption, having already been proved in Miocene porcupines in their dens and outside of them can be proved again for the Pleistocene species in Europe. It seems as if the intensive chewing on the herefigured bone fragments of hyena prey bone accumulations by Late Pleistocene spotted hyenas was a special and easy to obtain source, which they found in the caves or outside hyena dens. Here three of such hyena dens from Germany (Saalfeld) and the Czech Moravian Karst (Sveduv stul Cave and Javorka Cave) or Reporyje-Kalvarie Cave (Bohemian Karst) have delivered few, but typically by the large rodent Hystrix chewed bone fragments (Figs. 5, 7). For sure Hystrix did not import the large bones figured here, and most probably also not the bone fragments. Hyena dens and prey depots had a high amount of bones, which must have been recycled by porcupines in the caves itself. 
The rareness of porcupine remains in the Middle European Late Pleistocene can be easily explained with the porcupine den caves, as is for the Miocene [16]. The Late Pleistocene Hystrix animals usually died mainly in the caves (similar to modern Hystrix) and rarely outside of them. Possibly in some cases, these animal carcasses were imported by hyenas into their dens. The chance to find porcupine remains outside a cave is probably less then $0,1 \%$.

It is well-known that modern African Hystrix (H.) cristata porcupines use with their "families," natural cavities [19-21]. The old world porcupine H. cristata shelters in caves, rock crevices, aardvark holes, or burrows they dig themselves [20]. This can also be proved more recently using the oldest porcupines of Europe, being the ancestors of the old world porcupines, in the Miocene [16], and can additionally be shown here for the Pleistocene porcupines, whose behavior is quite typical.

Modern crested porcupines are active all year round, mainly at night and spend their time in these natural caves or burrow dens during the day [19-21], which can be expected for their ancestors as well. Burrow systems, which are in dry areas, can often be quite extensive and were used for many years [17]. Such open air site burrows may have been present in loess deposits such as the Early Weichselian site Praha-Kotlarská (Czech Republic). Natural cavities such as the here-presented small Fuchsluken Cave was a perfect porcupine den shelter because of its small size. Interestingly, hyena and porcupine den caves commonly overlap in the Pleistocene because both used small caves, which cave bears often could not enter to hibernate.

Five Hystrix species can be distinguished in the Pleistocene of Asia with $H$. (A.) lagrelli Lönnberg 1924, $H$. (A.) brachyura Linnaeus $1758, H$. $(H$.) kiangsenensis Wang 1931, $H .(H$.$) refossa Gervais 1852$ and probably $H .(H$. indica Kerr 1792. Only two species occurred in the Pleistocene of Europe with $H$. (A.) brachyura Linnaeus 1758 and $H$. $(H$.$) refossa Gervais 1852$ [1].

The European $H$. brachyura remains range from the Early Pleistocene [22] to the Late Pleistocene [23, 24]. The five recent extant species of porcupines are living with e.g. $H$. (A.) brachyura in southeast Asia, $H .(H$.$) indica in$ southwest Asia and H. (H.) cristata in northern Africa [18].

The recently known localities in Europe [1] are: Binagady (Azerbaijan), Kudaro (Georgia), Brassóv (Romania), Osztramos, Kiskohat, Varbó and Csobánka, Hungary [22], Medvednica, Slovenia [23], Ostrov and PrahaKotlarska in the Bohemian Karst, and Svedûv stûl Cave, Moravian karst, Czech Republic [25], Fuchsloch near Siegmannsbrunn, Bavaria, Southern Germany [26, 27], and

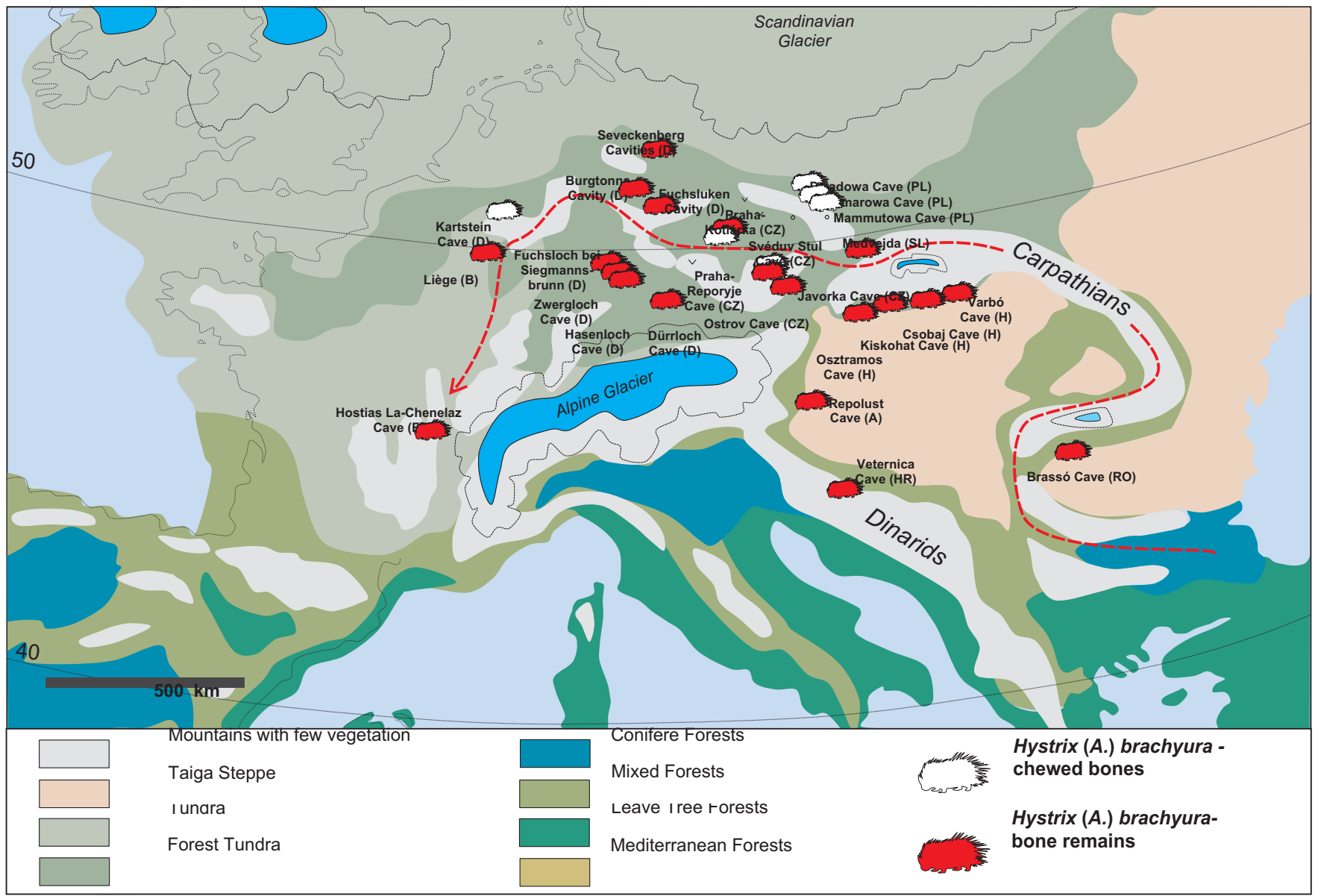

Fig. (8). Known Hystrix (Acanthion) brachyura Linnaeus 1758 localities in Europe with the new added localities and migration model from Asia over the Carpathians to northern Germany. Glaciers are figured in their Early Weichselian and in lines with their maximum extensions in the Late Weichselian maximum cold period. 
the Cave of Hostias-La Chênelaz, Ain, France [28], and Repolust Cave, Austria [29]. Historically mentioned German sites are the Zwergloch Cave und Hasenloch Cave near Pottenstein in Bavaria, South Germany [2]. Other remains were found in the Hoesch Cave Bavaria, South Germany [2], Finally in the Dürrloch Cave near Regensburg a mandible remain was figured [31].

Anyway the occurrence of those $H$. (A.) brachyura in the Eemian interglacial and Early Weichselian was finally called Hystrix-Hovizont", which indicates an isochronous distribution of those porcupines in the Late Pleistocene [29]. Whereas several authors believe Hystrix to be a warm period animal Germany [2, 25, 28, 30-34] arguments for an Eemian interglacial fauna of Hystrix horizons are well present at least in the Repulost Cave, Austria [29] and also here partly at the Fuchsluken Cave Saalfeld, Germany. The study of the Reporje-Kalvarie Cave, Czech Republic, contains an Eemian warm period fauna, but also some cold fauna from different layers of which here a bovid scapula with bite marks is presented (Fig. 6).

Hystrix chewed hyena prey bones have recently been discovered in the Komarowa Cave hyena den, the Dziadowa Cave hyena den and the Mammutowa Cave in southern Poland [14]. These are identified here to be of Hystrix origin with its similar large rectangular bite scratch marks, which are also observed on the Saalfeld hyena den cave bones. These cave sites are newly added here into the palaeobiogeographical distribution map of Europe, whereas the East-Asia sites mentioned [1] are not included. The two Thuringian sites, Burgtonna [3], and the here- described material from Saalfeld and the indirect proof using a chewed bone from the Kartsein Cave [7], all in Germany, can be finally added to the recently 21 known Late Pleistocene Weichselian porcupine sites, which are mainly cave sites (Fig. 8). Those even include three new caves in Czech Republic added here with some teeth and four chewed bones from the Švédův stůl Cave, three chewed bones from the Javorka Cave, both sites located in the Moravian Karst. Finally the Reporyje Cave near Prague (Bohemian Karst) has one chewed scapula.

These porcupines migrated from southern Russia and Asia to Central Europe only during the Early Weichselian cold arid period [1,8] along with e.g. Allactaga major (Kerr 1792), which was already figured with one bone from the Rote Berg [8]. At that time, dry and cold winds from the Scandinavian ice shields had the most impact on the vegetation and fauna; for example, rodents in Central Europe [24]. Hystrix remains of the Weichselian in Europe seem to occur in the forest tundra vegetation zone in mountainous regions (Fig. 8).

Hystrix remains are very useful for the age determination of macrobone assemblages since the Miocene [11, 12]; such as the Fuchsluken Cave, which can be determined to be at least partly from this Late Pleistocene (Early Weichselian) age.

\section{CONCLUSION}

The small caves in the karst of the Roter Berg near Saalfeld reflect a hyena den site mainly from the Early Weichselian time (Late Pleistocene) at which cubs were raised up. Cub teeth and bones and many chewed bones including "nibbling sticks", uni- or bipolar chewed bone fragments and a high amount of about $30 \%$ hyena remains prove well hyena den cavities. Around those small cavities prey remains were accumulated. A steppe bison hyena prey dominance can be observed. This den site was also periodically used by red foxes and badgers and finally by porcupines. Those used the cavities, when there were spread around many bones and fragments left by hyenas. Hytsrix recycled several of those bones and left only for their genus typical wide rodent bite marks often all around the bone fragments, which were unrecognized in many collections yet. Those porcupines were typical in Central Europe in the Early Weichselian cold period and occupied generally only small and not large caves, such as modern old world porcupines do. Finally the chewed bone material from the Rote Berg is useful to prove indirectly those animals now at several other caves in Europe, where porcupine bones or teeth are absent. The small teeth and their proportions fit well to the only known European Late Pleistocene porcupine species Hystrix (Acanthion) brachyura Linnaeus 1758, which seem to have immigrated from the steppe environments of Asia to Central Europe in the Early Weichselian of the Late Pleistocene, where it can be proved now at 20 caves and only one open air site.

\section{ACKNOWLEDGEMENTS}

The bone preparation and inventory of the historical Meyer collection in 2008 was sponsored by the Stadtmuseum im Franziskanerkloster Saalfeld, for which I acknowledge Dr. D. Henning. Free access to the collection of the Museum für Naturkunde Berlin of the Humboldt University was possible due to the kindness of PD Dr. O. Hampe. It was possible to study some bones in the Naturkundemuseum Gera collection with the support of Dr. C. Russe. The material from the Bohemian and Moravian Karst (Czech Republic) was allowed to study by the permissions of doc. PHDr. M. Oliva and the kind support of Mgr. T. Trubačova, Mgr. P. Kašpárek from the Anthropos Museum Brno (Czech Republic). The spell-check was performed by J. Ynsuna.

\section{REFERENCES}

[1] Weers Van DJ. A taxonomic revision of the pleistocene hystrix (hystricidae, rodentia) from eurasia with notes on the evolution of the family. Contrib Zool 2005; 74 (3/4): 301-12.

[2] Ranke J. Das zwergloch und hasenloch bei Pottenstein in Oberfranken. Beitr Anthrop Urg Bayerns 1879, 2: 209-10.

[3] Maul L. Erster nachweis von hystrix in der pleistozän-fundstelle burgtonna (thüringen, mitteldeutschland). Säugetierk Inf 1994; 18 (3): 673-82.

[4] Auerbach A. Die vor- und frühgeschichtlichen Altertümer Ostthüringens. Jena 1930.

[5] Meyer H. Reste diluvialer tiere und die ältesten menschenspuren vom rotenberg bei saalfeld. Thür Fähnl Monatsschr mitteld Heimat 1933 II; 5: 1-297.

[6] Stehlin HG, Graziosi P. Ricerche sugli Asinidi fossili d' Europa. Mem Soc Paleont Suisse 1935; 56: 73.

[7] Stehlin HG, Graziosi P. Occurrence of mammalia relicts at site roter berg bei saalfeld pangaea. 2001; doi:10.1594/PANGAEA. 63894.

[8] Koenigswald W Von. Lebendige Eiszeit. Klima und Tierwelt im Wandel. Theiss-Verlag: Darmstadt 2002.

[9] Liebe KT. Die lindentaler hyänenhöhle und andere diluviale knochenfunde in ostthüringen. Arch Anthr Org dt Ges Anthrop Ethnogr Urgesch 1876; 9: 1-55. 
[10] Soergel W. Die stellung der hyaena spelea GoLDF. Aus der lindentaler hyänenhöhle bei gera. Beitr Geol Thür 1937; 4 (5): 17189.

[11] Weers DJ Van, Rook L. Turolian and ruscinian porcupines (genus hystrix, rodentia) from Europe, Asia and North Africa. Paläont Z 2003; 77 (1): 95-113.

[12] Diedrich C. By ice age spotted hyenas protracted, cracked, nibbled and chewed skeleton remains of coelodonta antiquitatis (Blumenbach 1807) from the lower weichselian (upper pleistocene) open air prey deposit site bad wildungen-biedensteg (Hessia, NW Germany). J Taphonomy 2006; 4 (4): 173-205.

[13] Diedrich C, Žák K. Prey deposits and den sites of the upper pleistocene hyena crocuta crocuta spelaea (goldfuss 1823) in horizontal and vertical caves of the bohemian karst (Czech Republic). Bull Geosci 2006; 81 (4): 237-76.

[14] Wojtal P. Zooarchaeological studies of the Late Pleistocene sites in Poland. Drukarnia Kolejowa: Krakow 2007.

[15] Mikuláš R, Kadlecová E, Fejfar O, Dvořák Z. Three ichnogenera of biting and gnawing traces on reptilian and mammalian bones: a case study from the miocene of the Czech Republic. Ichnos 2006; 13: 1-15.

[16] Diedrich C. Porcupines in the bohemian karst - excavation results of the first known miocene hystrix (hystrix) parvae (Kretzoi 1951) cave den in Central Europe. Scr Facult Sci Univ Masarykianae Geol 2007; 35: 129-34.

[17] Nowak RM. Walker's Mammals of the World. 5th Edition, Vol. I. Baltimore:Johns Hopkins University Press 1991; Vol I.

[18] Storch G. Porcupines. In: Grzimek B, Ed. Grzimek' s Encyclopedia of Mammals. New York: McGraw-Hill 1990; 300-7.

[19] Alkon PU, Olsvig-Whitaker L. Crested porcupines digs in the negev desert highlands: pattern of density, size and longevity. J Arid Environ 1989; 17: 83-95.

[20] Pigozzi G, Paterson J. Movements and diet of crested porcupines in the maremma natural park, central Italy. Acta Theriologica 1990; 35: $173-80$.
[21] Corsini M, Lovari S, Sonnino, S. Temporal activity patterns of crested porcupines Hystrix cristata L., 1758. Zool J Linn Soc Lond 1995; 236: 43-54

[22] Jánossy D. Ein kleiner hystrix aus dem altpleistozän der fundstelle osztramos 8 (nordungarn). Vert Hungaric 1972; 13: 163-82.

[23] Malez M. Die quartaire fauna der hőhle veternica (medvednicakroatien). Paleont Jugoslavia 1963; 5: 1-193.

[24] Schweitzer M. Grotte de chenelaz (hostias, ain, france): les grands mammiferes de la couche 6b. Rev Paléobiologie 2002; 21: 803-18.

[25] Musil R Die Höhle Svedûv stûl, ein typischer Hyänenhorst. Anthropos 13NS5 1961; 13: 97-260.

[26] Heller F. Zur diluvialfauna des fuchsloches bei siegmansbrunn, landkr pegnitz. Geol Blätter NO-Bayern 1955; 5: 49-70.

[27] Brunner G. Das Fuchsloch bei Siegmannsbrunn (Oberfr.) (Eine meditterane Riss-Würm-Fauna). N Jb Geol Paläont 1954; 100: 83118.

[28] Hernández Fernández M. Rodent paleofaunas as indicators of climatic change in Europe during the last 125,000 years. Quat Res 2006; 65 (2): 308-323.

[29] Mottel M. Neuer beitrag zum hystrix-horizont europas. Ann Naturhist Mus Wien 1967; 71: 305-27.

[30] Nehring A. Über diluviale hystrix-reste aus bayrisch oberfranken. Sitzungsb Ges Naturf Freunde Berlin 1891: 10.

[31] Janossy D. Letztinterglaziale Vertebratenfauna aus der kaiman lambrecht-höhle, bükk-gebirge, NO-ungarn. II. Acta Zool Acad Sei Hung 1964; 10: 1-2.

[32] Stromer E v Lehrbuch paläozoologie. II. Teil: Wirbeltiere. Leipzig : Teubner 1912.

[33] Schmerling P-C Recherches sur les ossements fossiles, découverts dans les cavernes de la province de Liège. Liège, Collardin 1833.

[34] Dawkins WB, Sandforth WA. British Pleistocene mammalian. Part IV. Palaeontographical Society London 1871. 